\title{
SCHISTOSOMA MANSONI: COMPARATIVE EVALUATION OF DIFFERENT ROUTES OF EXPERIMENTAL INFECTION
}

\author{
M. TENDLER (1), R. Magalhães PINTO (1), Marcla CORTES (1) e Gisèle GEBARA (1)
}

\section{S U M M A $\mathbf{A} \quad \mathbf{R} \quad \mathbf{Y}$}

Experiments were carried out with Sw albino mice and it was concluded that the percutaneous route via abdominal skin was significatively more efficient than tail immersion method and subcutaneous infection; the subcutaneous injection was significatively more efficient than the percutaneous infection through the tail; this latter and the intraperitoneal injection, resulted in similar infections, but were significatively less efficient than the others. Significative difference was also observed in the comparison between the subcutaneous route and percutaneous infection through ear pinna. The influence of the site of skin infection by percutaneous route was also discussed.

\section{NTRODUGTIO N}

In most of experimental research on chemoterapy and immunology of schistosomiasis, workers frequently judge the success or failure of their attempts to cure or immunize different hosts, from the ratio of the number of living adult worms recovered, to the number of infecting cercariae.

This ratio is affected however, not only by the efficacy of any treatment, but also by the methods used to infect the animals and to recover the worms. In this respect, methods for experimental infection with $\mathbf{S}$. mansoni cercariae, such as percutaneous exposure (OLIVER \&: STIREWALT ${ }^{6}$; SMITHERS \& TERRY ${ }^{10}$; LIN et al. ${ }^{3}$ ) intraperitoneal inoculation (MOORE \& MELENEY ${ }^{5}$ ) or intravenous injection (HOLANDA et al. ${ }^{2}$ ) have been currently used in an attempt to study hosts susceptibility, route of cercarial infection and number of worms recovered, according to the experiment to be assessed. The subcutaneous injection of cerca- riae has been also preconized regarding its efficacy and practicability (PETERS \& WARREN ${ }^{8)}$. However, more recently, besides these evaluated parameters, the importance and interference of the skin in the acquired immunity to $\mathbf{S}$. mansoni infection, have been suggested (MILLER \& SMITHERS ${ }^{4}$ ).

Considering these data, it was found to be useful to investigate whether the infection routes could be used indiscriminately, based on their efficacy.

In this paper, not only these routes of infection are compared among themselves, but also different sites of exposure in the percutaneous infection with $\mathbf{S}$. mansoni, such as ab. dominal region, tail and ear pinna, besides subcutaneous inoculation over passing the skin, which is considered a probable site of death of the schistosomulae (SMITHERS \& GAMMA. $\left.\mathrm{GE}^{9}\right)$.

(1) Bolsistas do Conselho Nacional de Desenvolvimento Cientifico e Tecnologico (CNPq) Laboratório de Esquistossomose, Dept.o de Helmintologia, Instituto Oswaldo Cruz Address for reprints: Miriam Tendler - Fiocruz. Caixa Postal $926-20.000$ Rio de Janeiro, Brasil 
TENDLER, M.; PINTO, R. M.; CORTES, M. \& GEBARA, G. - Schistosoma mansoni: comparative evaluation of different routes of experimental infection. Rev. Inst. Med. trop. São Paulo 27:111-114, 1985.

\section{MATERIAL AND METHODS}

Mice

Sw outbred male albino mice weighthing 20-25g, from Oswaldo Cruz Institute were used in all experiments.

\section{S. mansoni}

LE strain from Belo Horizonte was used. Cercariae were obtained from Biomphalaria glabrata colonized in our laboratory and were shed by forty snails put under artificial light in $300 \mathrm{ml}$ of destilled water for each experiment. The cercarial suspension was then transferred to another container and counted. It was used $100 \pm 20$ cercariae from the same pool per mouse.

\section{Infection Procedures: Percutaneous exposure}

Three different sites of infection were com. pared: abdominal region infection assessed by the "ring method" according to SMITHERS \& TERRY ${ }^{10}$, tail immersion method (OLIVIER \& STIREWALT ${ }^{5}$ ) and ear pinna exposure as described by MILLER \& SMITHERS ${ }^{4}$. For the first two above mentioned regions, the mice were immobilized without anesthesics as referred elsewhere (TENDLER \& PINTO 11 ) and to allow the cercariae penetration they were exposed for $45 \mathrm{~min}$ aproximatedly, that was the time period after which no alive cercariae could be seen in the suspension.

For infection via the ear, holes $20 \mathrm{~mm}$ in diameter were drilled in a $13 \mathrm{~mm}$ thick wood block. In each hole it was inserted a $15 \mathrm{~mm}$ deep plastic container. Mice were anaesthetized with 10-25 $\mu \mathrm{g} /$ mouse of Thionembutal (Abbot), and laid on the wood block so that three quarters of the ear pinna was immersed in the cercarial suspension.

\section{Subcutaneous and intraperitoneal infections}

Performed in unanaesthetized and manually immobilizated mice, inoculated with cercariae from the same pool. The syringe and needle were those used for counting the cercariae. In the subcutaneous inoculation (PETERS \& WAR$R E N{ }^{8}$ ) the skin in the neck region was lifted and the needle gently introduced. Mice intra- peritoneally inoculated, were maintained in supine position. Seven experiments were carried out in two stages. Initially four experiments were assessed, comparing the percutaneous (abdominal region and tail), subcutaneous and in. traperitoneal routes, with 20 mice in the first two groups, and 10 in the third and fourth. Another three additional experiments were assayed concerning the comparison between per. cutaneous infection via ear pinna and subcutaneous infection, with 5 mice per group.

\section{Adult worm recovery}

Forty five days after infection, by the different tested routes the worm burdens were evaluated after perfusion with saline $(0.85 \% \mathrm{NaCl})$ of the mesenteric and hepatic venous systems (PELLEGRINO \& SIQUEIRA ${ }^{7}$ ).

\section{Statistical analysis}

The results were analysed by using $\mathrm{F}$ test (one way no replications) to check the significance of the difference between adult worm mean recoveries (BAILEY ${ }^{1}$ ).

\section{RESULTS}

The results so far obtained in seven experiments are expressed by the mean worm recovery from the mice infected through the different routes.

From the analysis of the results, it was concluded that: the percutaneous route through the abdominal region ("ring method") ( $\bar{x}=42.93$ worms recovered) was more effective than the subcutaneous injection $(\bar{x}=33.10, p<0.001)$ and percutaneous route through the tail $(\overline{\mathrm{x}}=$ $13.59, \mathrm{p}<0.001)$. The intraperitoneal injection $(\bar{x}=19.93)$ was less efficient than the former $(\mathrm{p}<0.001)$ although resulting in similar infection pattern when compared to the percutaneous tail immertion route $(\bar{x}=13.59$ ) (Table I).

In additional experiments the subcutaneous route $(\bar{x}=17.64)$ was compared to the infection through ear pinna $(\bar{x}=10.15)$, when the former showed to be more effective $(p<0.001)$, considering parasitic burden recovery (Table [I). 
TENDLER, M.; PINTO, R. M.; CORTES, M. \& GEBARA, G. - Schistosoma mansonl: comparative evaluation of different routes of experimental infection. Rev. Inst. Med. trop. São Paulo 27:111-114, 1985.

\section{T A B I E I}

Schistosoma mansoni: Comparative evaluation of different routes of experimental infection in $\mathrm{SW}$ Albino mice infected with $100 \pm 20$ cercariae/animal

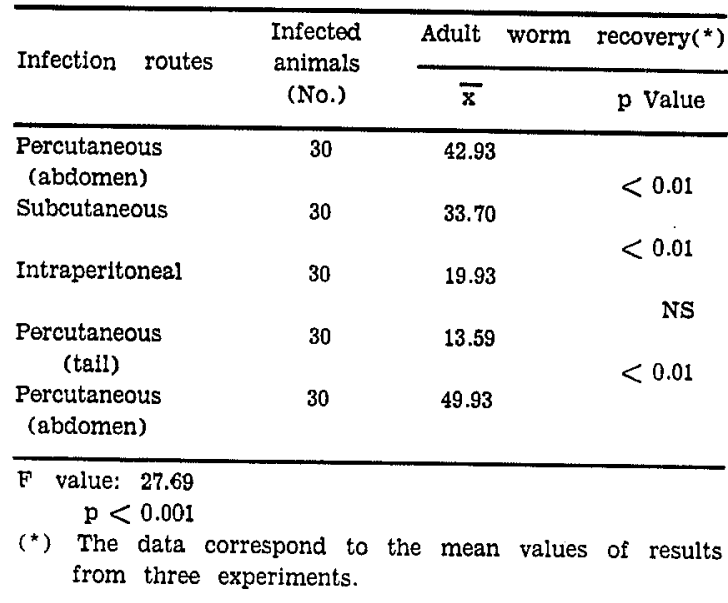

T A B L E II

Schistosoma mansoni: Comparative evaluation between sub. cutaneous and percutaneous (ear pinna) routes of experimental infection in five SW albino mice/experiment, with $100 \pm 20$ cercariae per animal

\begin{tabular}{lcc}
\hline & & Adult worm recovery( ${ }^{*}$ ) \\
Infection routes & $\bar{x}$ & p Value \\
\hline Subcutaneous & 17.64 & $<0.001$ \\
Percutaneous \\
(Ear pinns) \\
\hline F value: 27.69 \\
$\quad$ p $<0.001$
\end{tabular}

\section{DISCUSSION}

The data here presented can be analysed emphasizing two aspects.

The evaluation of the intraperitoneal route of infection showed to be similar to data obtain. ed before (WATSON \& AZIM ${ }^{12}$; MOORE \& MELENEY ${ }^{5)}$ regarding the fact that it was less efficient and found to be not indicated for current use. Nevertheless, it is important to point out that when the subcutaneous injection was compared to percutaneous route of infection, it was evident that the site of infection was the principal factor affecting the efficacy of this route. So, in the comparison of the mean worm burden from animals infected through the abdomi- nal skin, was significatively more effective than the subcutaneous injection.

On the other hand, this situation was reversed in the comparison between subcutaneous injection and tail infection, the former showing to be significatively more efficient than the latter as well as than percutaneous infection through ear pinna.

Our results are in agreement with those of PETERS \& WARREN 8, with respect to the greater effectiveness of the cercarial subcutaneous injection when compared to the percutaneous infection through the tail. However, it was evidentiated that this relation was opposite in the confrontation between subcutaneous route and the percutaneous infection through abdominal skin.

Thus, we judged of practical importance the data here presented regarding the evidences that the region of skin infection could modify the efficacy of the percutaneous route, that has been considered preferential by a great number of workers, since it reproduces with more accuracy the natural infection by $\mathbf{S}$. mansoni and, as recently suggested, (SMITHERS \& GAMMAGE ${ }^{9}$ ) may be an important step for the hosts mechanisms of immunity against the parasite.

\section{RESUMO}

\section{Schistosoma mansoni: avaliação comparativa de diferentes vias de infecção experimental}

Foram realizados experimentos com camundongos SW albinos, para se estabelecer a comparação entre diferentes vias de infecção por cercárias do S. mansoni: inoculação subcutânea, infecção percutânea em três áreas distintas e injeção intraperitoneal. Os animais foram infectados simultaneamente com cercárias de um mesmo lote. A avaliação da infecção foi realizada 45 dias após, por perfusão do sistema porta hepático e mesentérico e contagem dos vermes recuperados. Com base nos resultados obtidos podemos dizer que a infecção percutânea na região abdominal se mostrou a mais eficiente, seguida pela infecção subcutânea. Com relação às infecções intraperitoneal e percutânea pela cauda, concluímos que são semelhantes entre si porém diferem muito, das duas primeiras. 
TENDLER, M.; PINTO, R. M.; CORTES, M. \& GEBARA, G. - Schistosoma mansoni: comparative evaluation of different routes of experimental infection. Rev. Inst. Med. trop. São Paulo 27:111-114, 1985.

Mais um grupo experimental foi incluido neste trabalho, seguindo-se a mesma metodologia utilizada nos grupos anteriores. O objetivo das experiências complementares foi a avaliação comparativa da eficiência da via percutânea no pavilhão da orelha em relação a via subcutânea. A influência do sítio da pele, utilizado na infecção pela via percutânea, foi também discutida.

\section{ACKNOWLEDGMENTS}

This investigation was partially supported by Conselho Nacional de Desenvolvimento Científico e Tecnológico (CNPq, Brazil), grant $n .{ }^{\circ}$ 04.3800/82-PIDE-V. We are indebted to Mrs. Daisy Surerus Campos and Dr. Luiz Carlos Sauerbronn Maia for the statistical analysis.

\section{REFERENCES}

1. BAILEY, N. T. J. - Statistical Methods in Biology. London, The English Universities Press, 1969.

2. HOLANDA, J. C. : PELLEGRINO, J. \& GAZZINELLI, G. - Infection of mice with cercariae and schistosomula of Schistosoma mansoni by intravenous and subcuta. neous route. Rev. Inst. Med. trop. São Paulo 16: 132$134,1974$.

3 LIN, J-H-; FANG, W. S. \& HUANG, R. J. - A new method for percutaneous infection of mice with cercariae of Schistosoma mansoni: wet method. Mem. Coll. Agric. Nat. Taiwan Univ. 15: 172-178, 1974.

4. MILLER, K. L. \& SMITHERS, S. R. - Schistosoma mansoni: The attrition of a challenge infection in mice immunized with highly irradiated liver cercariae. Exp. Parasitol. 50: 211.212, 1980.
5. MOORE, D. V. \& MELENEY, H. E. - Development of Schistosoma mansonl in the peritoneal cavity of mice. J. Parasitol. 41: 235-245, 1955.

6. OLIVIER, I. \& STIREWALT, M. A. - An efficient method for exposure of mice to cercariae of Sehisto. soma mansonl. J. Parasitol. 38: 19-23, 1952.

7. PELLEGRINO, J. \& SIQUEIRA, A. F. - Técnica de perfusão para coleta de Schistosoma mansoni em co. baias experimentalmente infectadas. Rev. Bras. Mala. riol. Doenças Trop. 8: 589-597, 1956.

8. PETERS, P. A. \& WARREN, K. S. - A rapid method of infecting mice and other laboratory animals with Schistosoma mansoni: Subcutaneous injection. J. Pa. rasitol. 55: 558, 1969.

9. SMITHERS, S. R. \& GAMMAGE, K. - Recovery of Schistosoma mansoni from the skin, lungs and hepatic portal system of naive mice and previously exposed to Schistosoma mansoni: Evidence for two phases of parasitic attrition in immune mice. Parasitol. 80: 289300,1980 .

10. SMITHERS, S. R. \& TERRY, R, J. - The infection of laboratory hosts with cercariae of Schistosoma mansoni and the recovery of adult worms. Parasitol. 55: $695-700,1965$.

11. TENDLER, M. \& PINTO, R. M. - A simple device to immobilize mice for infection with Schistosoma mansoni cercariae. J. Parasitol, 67: 583-584, 1981.

12. WATSON, J. M. \& AZIM, M. A. - Comparative effi. ciency of various methods of infecting mice with Schistosoma mansoni. Ann. Trop, Med. Parasitol, 43: $41-46,1949$.

Recebido para publicação em $9 / 5 / 1984$. 